\begin{tabular}{|c|l}
\hline Construction and Material Journal & $\begin{array}{l}\text { Volume 1 No.2 } \\
\text { Juli } 2019\end{array}$ \\
\hline
\end{tabular}

\title{
EFFECT OF SHEAR WALL ON BUILDING STRUCTURE RESPONS
}

\author{
Wendi Boy $^{(1)}$, Rafki Imani(2), Romi Jaya ${ }^{(3)}$ \\ ${ }^{1,2}$ Dosen Jurusan Teknik Sipil, Universitas Putra Indonesia YPTK Padang, Jl. Raya Lubuk Begalung \\ Padang, Telp. 0751-73000, Website: www.upiyptk.ac.id \\ ${ }^{3}$ Alumni Jurusan Teknik Sipil, Universitas Putra Indonesia YPTK Padang, Jl. Raya Lubuk Begalung \\ Padang, Telp. 0751-73000, Website: www.upiyptk.ac.id
}

\begin{abstract}
Cibubur is an area in the earthquake zone. The intensity of the earthquake increases every year; therefore, this must be watched out because it will cause the existing buildings to be short-lived. To deal with these problems, various ways are carried out such as making building stiffeners in the form of a shear wall. This study aims to determine the position of an efficient shear wall. The method for analyzing this shear wall was first modeled. The shear wall laying model was divided into four. With the four models, it would be able to choose which model was efficient to reduce the earthquake that occured. Analysis used ETABS software on each model, and output in the form of drift and base shear. These results will become a reference for effective model selection. Based on the results of drift and base shear in the direction of $X$ and $Y$ direction, of the four shear wall placement models of Tower $B$ Trans Park and Trans Studio Cibubur, the most efficient in resisting earthquake loads is the original model. With a save value of direction $X$ is $926.62 \mathrm{~mm}$, and $Y$ is $931.22 \mathrm{~mm}$. The value of the base shear on direction $X$ is 4691.71 tons, and $Y$ is 4736.57 tons.
\end{abstract}

Keywords: Base shear, Drift, Earthquake; Shear wall

\section{PENDAHULUAN}

Gempa tidak dapat dicegah dan dapat menyebabkan dampak bagi manusia seperti kematian, kerusakan pada bangunan rumah tinggal dan fasilitas umum (Gambar 1.1). Cibubur merupakan salah satu kota metropolitan di daerah Jabodetabek, yang ditandai dengan banyak bangunan besar yang berdiri, serta berada pada wilayah gempa menengah (wilayah 3). Berdasarkan intensitas gempa di Indonesia, ini harus diwaspadai agar bangunan yang akan dibuat bisa bertahan dalam jangka waktu yang lama, sehingga dapat meminimalisir kerugian yang akan terjadi di masa mendatang.

Untuk menghindari dampak di atas, maka dibuat sebuah dinding pengaku gedung berupa shear wall. Shear wall adalah beton bertulang yang dibuat dari bawah bangunan sampai atas dengan penempatan yang bervariasi. Untuk mengetahui keefektifan shear wall maka dilakukan analisis menggunakan program aplikasi ETABS yang memberikan output berupa simpangan dan base shear.

Bangunan tinggi berbeda perhitungannya dengan bangunan pemukiman biasa [1], dimana perencanaannya dilakukan sesuai dengan kaedah dan standar bangunan menurut Standar Nasional Indonesia (SNI). Standar yang harus dipenuhi adalah seperti stabilitas dan kemampuan untuk menahan gaya lateral, baik yang disebabkan oleh angin maupun akibat gempa.

Beban angin sangat dipengaruhi oleh elevasi bangunan, yaitu seberapa tinggi bangunan yang akan dibuat akan dipengaruhi oleh beban angin yang semakin besar ke atas. 
Sedangkan beban gempa lebih terkait dengan massa bangunan. Bangunan yang tinggi perlu diperhatikan bagian kolomnya karena ada gaya lateral. Untuk meminimalisir gaya tersebut maka dibuat sistem pengaku, agar deformasi yang terjadi akibat gaya horizontal tidak melampaui ketentuan yang disyaratkan.
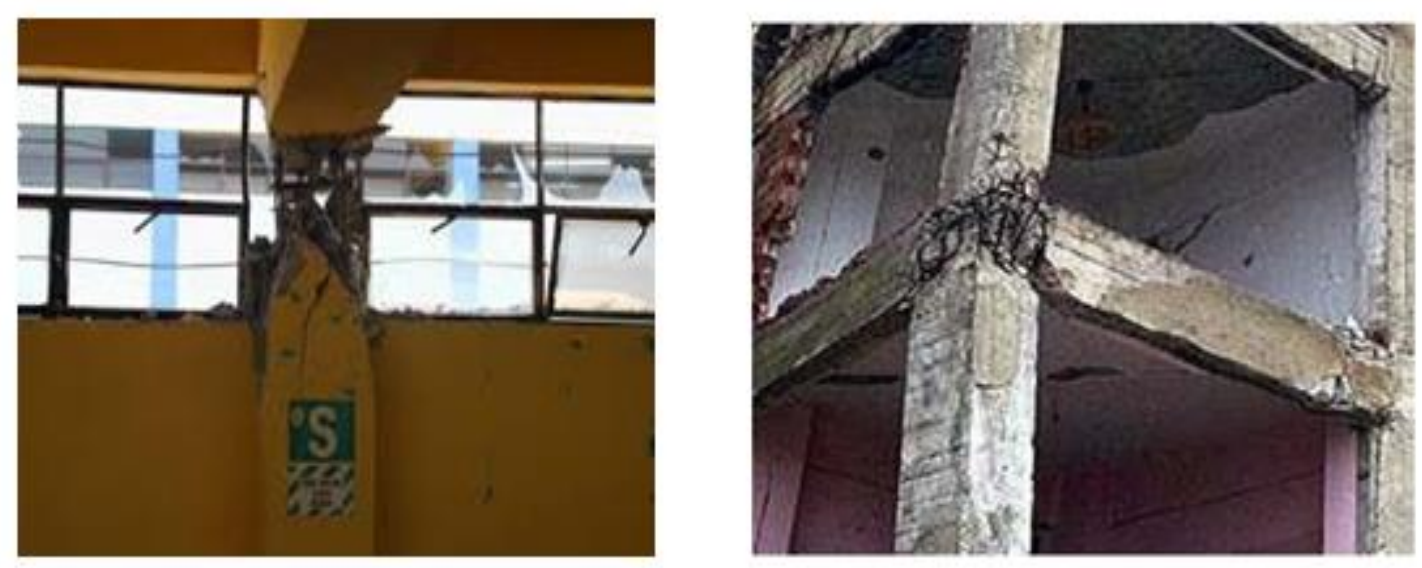

Gambar 1. Kerusakan akibat gempa [1].

Pengaku gaya lateral yang lazim digunakan adalah portal penahan momen, dinding geser atau rangka pengaku. Untuk rangka pengaku pada penelitian ini adalah shear wall. Untuk bisa meredam gaya lateral yang terjadi, harus dipahami apakah struktur berada pada kategori risiko I, II, III atau IV [2].

\section{METODOLOGI}

Metodologi penelitian ini adalah metode analisi menggunakan gempa dinamis respons spektrum, menggunakan software ETABS dengan empat buah pemodelan kemudian melakukan pembandingan dari hasil simpangan dan base shear. Tahapannya dilihat seperti di bawah ini:

Data bangunan gedung sebagai berikut:
a. Jenis struktur
b. Mutu beton (fc')
: Beton Bertulang
c. Modulus elastisitas (Ec) : 25742,96 Mpa
d. Angka poison (v) : 0,2
e. Modulus geser $(\mathrm{G}) \quad$ : $10726,23 \mathrm{Mpa}$
f. Mutu tulangan : Diameter $\leq 12 \mathrm{~mm}$ tulangan polos BJTP 24, tegangan leleh fy $=240 \mathrm{Mpa}$
Diameter > $12 \mathrm{~mm}$ Tulangan ulir BJTD 40
g. Jumlah lantai (n) tegangan leleh $\mathrm{fy}=400 \mathrm{Mpa}$
h. Tinggi gedung $(\mathrm{H})$
: 38
i. Luas bangunan (A)
$: 125,8 \mathrm{~m}$
j. Fungsi gedung
: $1153,64 \mathrm{~m}^{2}$
k. Jenis tanah
: Tempat tinggal
: adalah tanah lunak berdasarkan Gambar 1. 

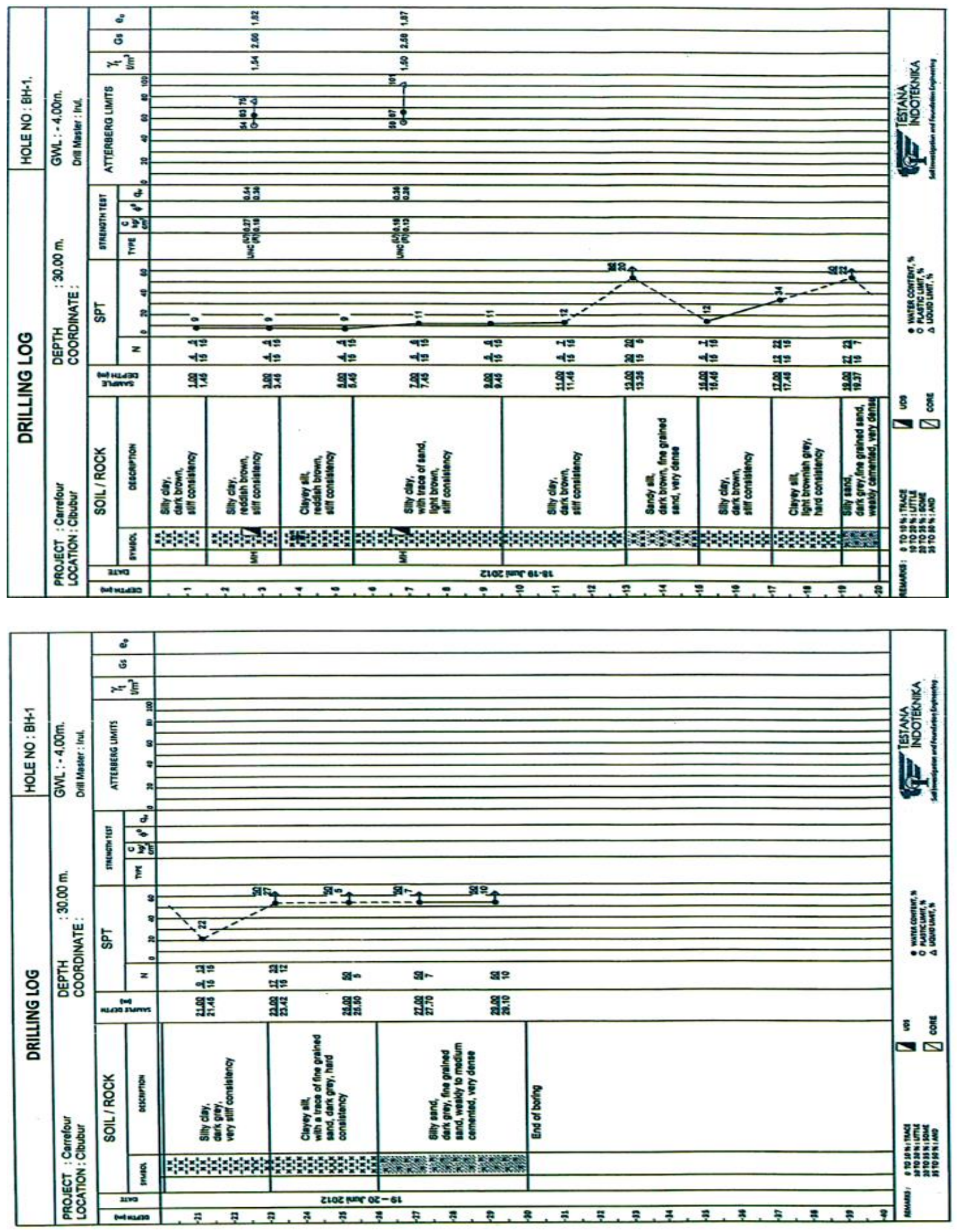

Gambar 1. Data tanah hasil pengukuran. 


\section{Pembebanan}

a. Beban mati

Beban mati yang ada pada bangunan ini adalah berat sendiri material yang ada pada bangunan, untuk menentukan berat beban mati dihitung dengan menggunakan berat jenis material diambil dari SNI 03-1727-1989 [3].

1. Beton bertulang $(B t) 2400 \mathrm{~kg} / \mathrm{m}^{3}$

2. Penutup lantai dari ubin semen plafon, teraso dan beton tampa adukan per cm tebal $(P l) 24 \mathrm{~kg} / \mathrm{m}^{2}$

3. Langit-langit, tampa penganting langit-langit atau pengaku $(L l) 11 \mathrm{~kg} / \mathrm{m}^{2}$

4. Pengantung langit-langit $(P l l) 7 \mathrm{~kg} / \mathrm{m}^{2}$

Berikut ini adalah cara menentukan beban tiap-tiap lantai

Diketahui:

1. Tebal lantai basement 2 (B2) sampai lower ground mezzanine (LGM) $0.2 \mathrm{~m}$

2. Tebal lantai ground floor (GF) sampai lantai lower ground mezzanine (LMR) machine room (LMR) $0.14 \mathrm{~m}$

Penyelesaian:

Lantai B2 sampai LGM dengan persamaan berikut

$$
\begin{aligned}
B & =(T l . B t)+P 1+L 1+P 11 \\
& =(0,2.2400)+24+11+7 \\
& =522 \mathrm{~kg} / \mathrm{m}^{2}
\end{aligned}
$$

Lantai GF sampai LMR dengan persamaan berikut

$$
\begin{aligned}
B & =(T l . B t)+P 1+L 1+P 11 \\
& =(0,14.2400)+24+11+7 \\
& =378 \mathrm{~kg} / \mathrm{m}^{2}
\end{aligned}
$$

b. Beban hidup

Untuk beban hidup yang bekerja pada bangunan diambil dari PPIUG 1983 yang diambil berdasarkan jenis dan fungsi gedung [4].

1. B2 sampai lower ground mezzanine (LGM)

$$
: 400 \mathrm{~kg} / \mathrm{m}^{2}
$$

2. Ground floor (GF) sampai (LMR) $\quad: 250 \mathrm{~kg} / \mathrm{m}^{2}$

3. Dak beton

$$
: 100 \mathrm{~kg} / \mathrm{m}^{2}
$$

c. Beban gempa

Beban gempa yang digunakan adalah gempa dinamik beban yang berubah-rubah menurut waktu begitu juga arahnya, beban gempa dihitung manual berdasarkan data tanah $S E$ kemudian didapatkan hasil sebagai berikut: 
Tabel 1. Tabel respon spektrum tanah lunak.

\begin{tabular}{|c|c|c|c|c|c|c|c|}
\hline $\begin{array}{c}\mathrm{T} \\
\text { (detik) }\end{array}$ & $\mathrm{Sa}(\mathrm{g})$ & $\begin{array}{c}\mathrm{T} \\
\text { (detik) }\end{array}$ & $\begin{array}{l}\mathrm{Sa} \\
(\mathrm{g})\end{array}$ & $\begin{array}{c}\mathrm{T} \\
\text { (detik) }\end{array}$ & $\begin{array}{l}\mathrm{Sa} \\
(\mathrm{g})\end{array}$ & $\begin{array}{c}\mathrm{T} \\
(\operatorname{detik})\end{array}$ & $\begin{array}{l}\mathrm{Sa} \\
(\mathrm{g})\end{array}$ \\
\hline 0,000 & 0,243 & 1,750 & 0,326 & 2,750 & 0,207 & 3,750 & 0,152 \\
\hline 0,191 & 0,600 & 1,850 & 0,308 & 2,850 & 0,200 & 3,850 & 0,148 \\
\hline 0,950 & 0,600 & 1,950 & 0,293 & 2,950 & 0,193 & 4,950 & 0,115 \\
\hline 1,050 & 0,543 & 2,050 & 0,278 & 3,050 & 0,187 & - & - \\
\hline 1,150 & 0,496 & 2,150 & 0,265 & 3,150 & 0,181 & - & - \\
\hline 1,250 & 0,456 & 2,250 & 0,254 & 3,250 & 0,176 & - & - \\
\hline 1,350 & 0,423 & 2,350 & 0,243 & 3,350 & 0,170 & - & - \\
\hline 1,450 & 0,393 & 2,450 & 0,233 & 3,450 & 0,165 & - & - \\
\hline 1,550 & 0,368 & 2,550 & 0,224 & 3,550 & 0,161 & - & - \\
\hline 1,650 & 0,346 & 2,650 & 0,215 & 3,650 & 0,156 & - & - \\
\hline
\end{tabular}

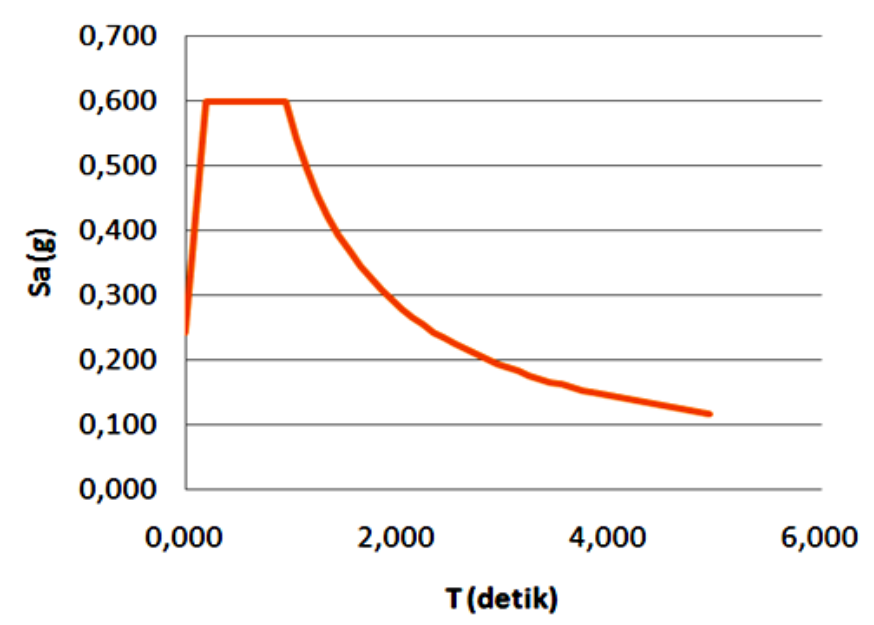

Gambar 2. Respon spektrum.

Kombinasi pembebanan gempa dalam penelitian ini menggunakan prosedur analisis spektrum respons ragam. Gedung termasuk dalam Kategori Desain Seismik (KDS) tipe D dengan persamaan berikut [5]:
a. $1,4 D L$
b. $1,2 D L+1,6 L L$
c. $1,41 D L+1 L L+0.39 Q E X+1.3 Q E Y$
d. $0,99 D L+1 L L-0,39 Q E X-1,3 Q E Y$
e. $1,09 D L+1 L L+0,39 \mathrm{Q} E X-1,3 Q E Y$
f. $1,31 D L+1 L L-0,39 Q E X+1,3 Q E Y$
g. $1,41 D L+1 L L+1,3 Q E X+0,39 Q E Y$
h. $0,99 D L+1 L L-1,3 Q E X-0,39 Q E Y$
i. $1,09 D L+1 L L-1,3 Q E X+0,39 Q E Y$
j. $1,31 D L+1 L L+1,3 Q E X-0,39 Q E Y$
k. $0,69 D L+0,39 Q E X+1,3 Q E Y$
1. $0,79 D L-0,39 Q E X+1,3 Q E Y$
m. $1,11 D L-0,39 Q E X-1,3 Q E Y$ 

n. $1,01 D L+0,39 Q E X-1,3 Q E Y$
o. $0,69 D L+1,3 Q E X+0,39 Q E Y$
p. $1,01 D L+1,3 Q E X-0,39 Q E Y$
q. $1,11 D L-1,3 Q E X-0,39 Q E Y$
r. $0,79 D L-1,3 Q E X+0,39 Q E Y$

\section{Pemodelan shear wall}

Dalam analisis ini digunakan empat buah pemodelan, yaitu model asli, model-1, model-2 dan model-3.

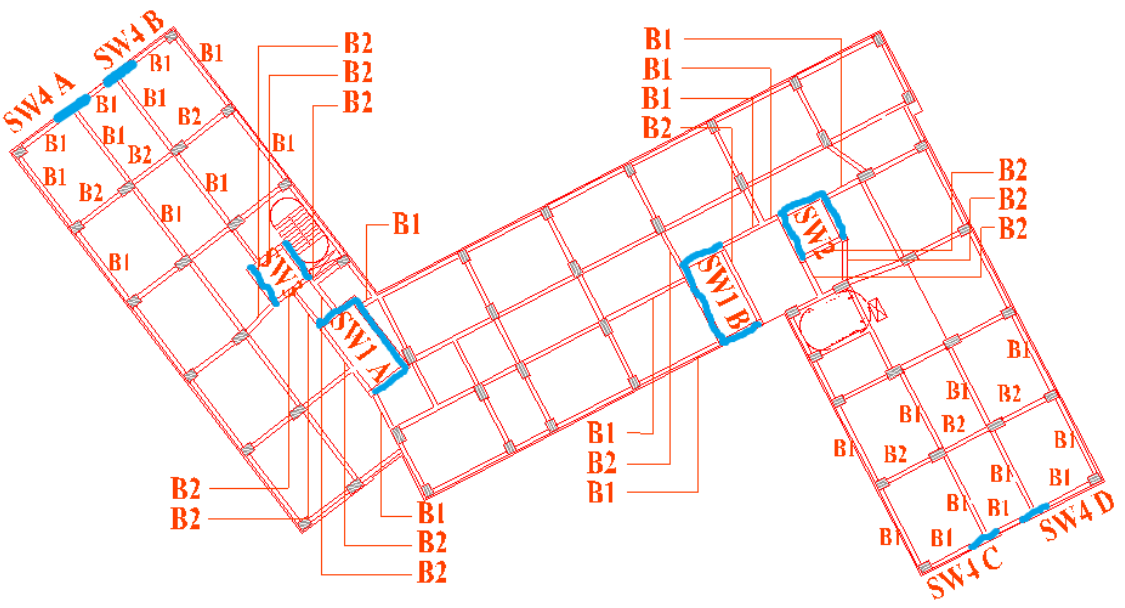

Gambar 3. Model asli.

Berdasarkan Gambar. 3 dapat dilihat dimana shear wall 3 (SW3) berada di antara empat buah balok B2, shear wall 1A (SW1A) berada di antara tiga buah balok B2 dan dua buah balok B1, shear wall 1B (SW1B) berada di antara dua buah balok B2 dan tiga buah balok B1, shear wall 2 (SW2) berada di antara dua buah balok B1 dan tiga buah di antara balok B2, shear wall 4A (SW4A) berada di antara tiga buah balok B1, shear wall 4B (SW4B) berada di antara tiga buah balok B1, shear wall 4C (SW4C) berada di antara tiga buah balok B1, shear wall 4D (SW4D) berada di antara tiga buah balok B1. Ukuran SW1A $=$ SW1B, sementara SW4A $=$ SW4B $=$ SW4C $=$ SW4D $=$ SW4E $=$ $\mathrm{SW} 4 \mathrm{~F}=\mathrm{SW} 4 \mathrm{G}=\mathrm{SW} 4 \mathrm{H}=\mathrm{SW} 4 \mathrm{I}=\mathrm{SW} \mathrm{J}=\mathrm{SW} 4 \mathrm{~K}=\mathrm{SW} 4 \mathrm{~L}$. 


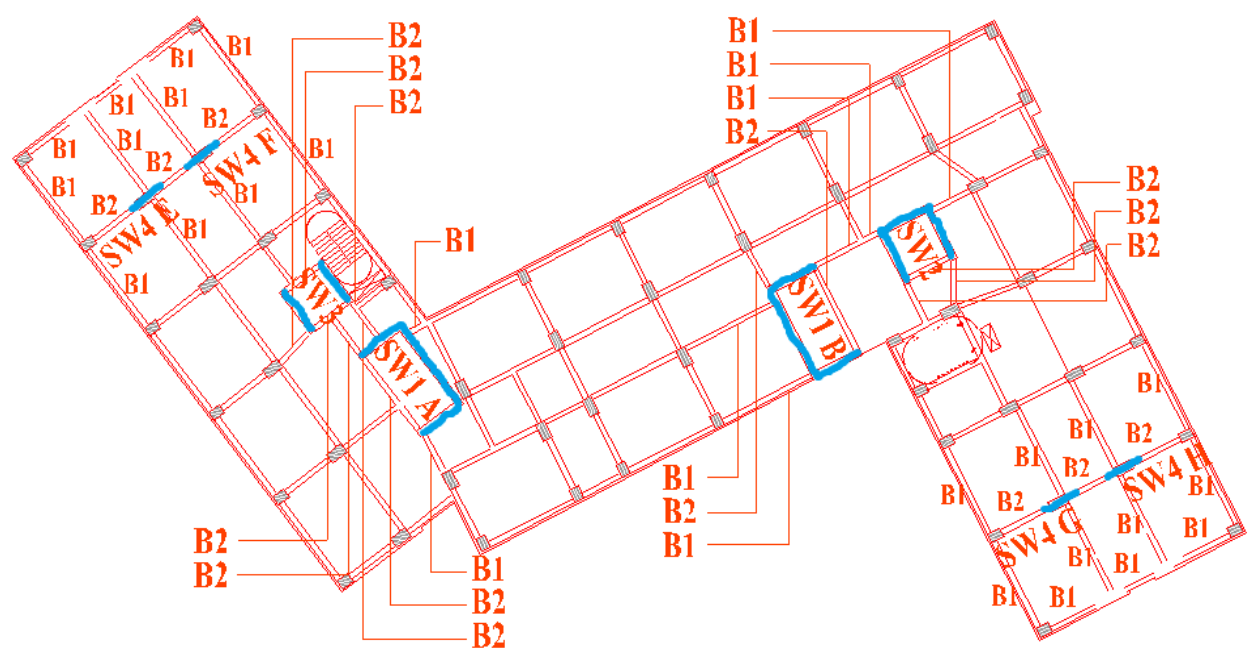

Gambar 4. Model-1.

Berdasarkan Gambar. 4, shear wall 3 (SW3) berada di antara empat buah balok B2, shear wall 1A (SW1A) berada di antara tiga buah balok B2 dan dua buah balok B1, shear wall 1B (SW1B) berada di antara dua buah balok B2 dan tiga buah balok B1, shear wall 2 (SW2) berada di antara dua buah balok B1 dan tiga buah di antara balok B2, shear wall 4A (SW4E) berada di antara dua buah balok B1 dan dua buah balok B2, shear wall 4B (SW4F) berada di antara dua buah balok B1 dan dua buah balok B2, shear wall 4C (SW4G) berada di antara dua buah balok B1 dan dua buah balok B2, shear wall 4D (SW4H) berada di antara dua buah balok B1 dan dua buah balok B2. Ukuran SW1A = SW1B, sementara SW4A = SW4B = SW4C = SW4D = SW4E = $\mathrm{SW} 4 \mathrm{~F}=\mathrm{SW} 4 \mathrm{G}=\mathrm{SW} 4 \mathrm{H}=\mathrm{SW} 4 \mathrm{I}=\mathrm{SW} 4 \mathrm{~J}=\mathrm{SW} 4 \mathrm{~K}=\mathrm{SW} 4 \mathrm{~L}$.

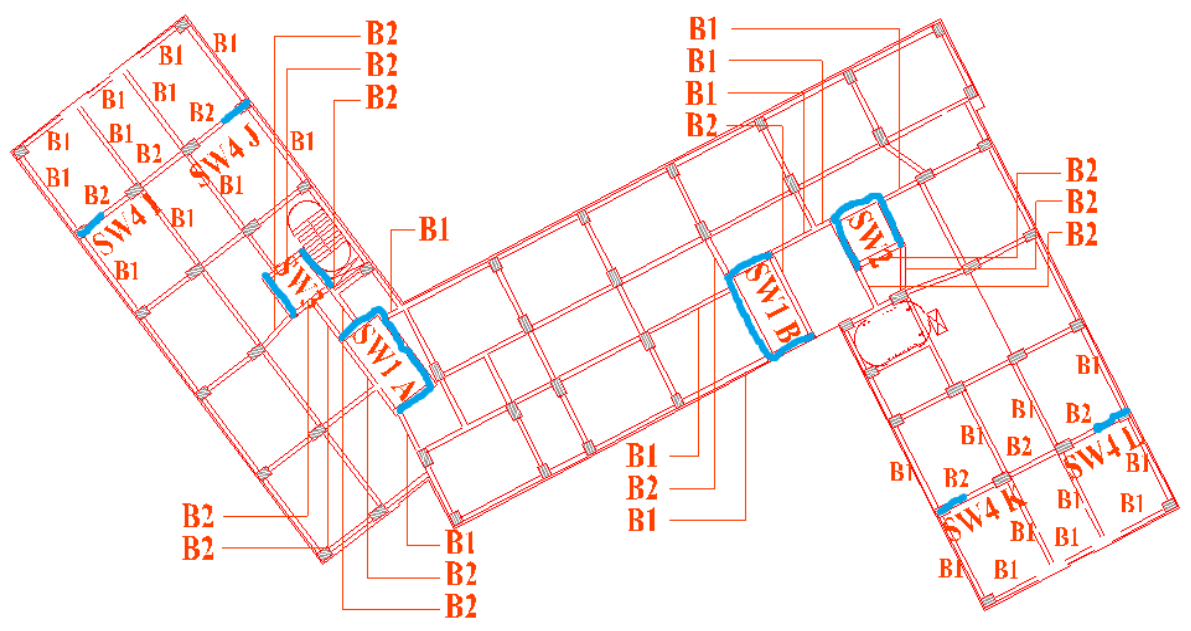

Gambar 5. Model-2.

Seperti Gambar. 5, shear wall 3 (SW3) berada di antara empat buah balok B2, shear wall 1A (SW1A) berada di antara tiga buah balok B2 dan dua buah balok B1, shear wall 1B (SW1B) berada di antara dua buah balok B2 dan tiga buah balok B1, shear wall 2 (SW2) berada di antara dua buah balok B1 dan tiga buah di antara balok B2, shear wall 4A (SW4I) berada di antara dua buah balok B1 dan satu buah balok B2, shear wall 
4B (SW4J) berada di antara dua buah balok B1 dan satu buah balok B2, shear wall 4C (SW4K) berada di antara dua buah balok B1 dan satu buah balok B2, shear wall 4D (SW4L) berada di antara dua buah balok B1 dan satu buah balok B2. Ukuran SW1A = SW1B, sementara SW4A $=$ SW4B $=$ SW4C $=$ SW4D $=$ SW4E $=$ SW4F $=$ SW4G $=$ $\mathrm{SW} 4 \mathrm{H}=\mathrm{SW} 4 \mathrm{I}=\mathrm{SW} 4 \mathrm{~J}=\mathrm{SW} 4 \mathrm{~K}=\mathrm{SW} 4 \mathrm{~L}$.

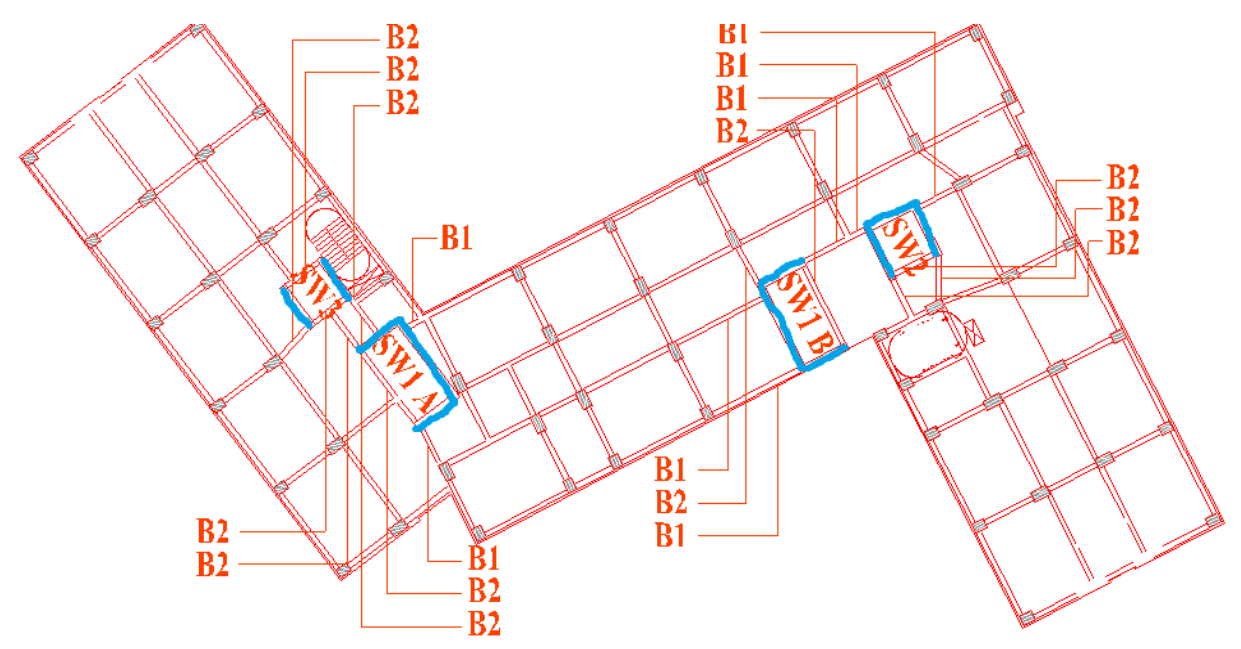

Gambar 6. Model-3.

Berdasarkan Gambar. 6 dapat dilihat dimana shear wall 3 (SW3) berada di antara empat buah balok B2, shear wall 1A (SW1A) berada di antara tiga buah balok B2 dan dua buah balok B1, shear wall 1B (SW1B) berada di antara dua buah balok B2 dan tiga buah balok B1, shear wall 2 (SW2) berada di antara dua buah balok B1 dan tiga buah di antara balok B2.

\section{HASIL DAN DISKUSI}

\section{Analisis Simpangan}

Analisis simpangan dibagi menjadi empat pemodelan dengan arah $\mathrm{X}$ dan $\mathrm{Y}$, seperti pada Tabel 2 dan 3.

Tabel 2. Simpangan arah X.

\begin{tabular}{cccccc}
\hline \multirow{2}{*}{ Lantai } & $\begin{array}{c}\text { Tinggi lantai } \\
(\mathrm{mm})\end{array}$ & \multicolumn{3}{c}{ Simpangan antar lantai arah X (mm) } \\
& & Model asli & Model 1 & Model 2 & Model 3 \\
\hline LMR ROOF & 122600 & 943,90 & 926,62 & 981,18 & 1003,67 \\
LMR & 119600 & 926,80 & 908,95 & 963,33 & 986,97 \\
32 & 114600 & 896,74 & 878,35 & 932,20 & 957,74 \\
31 & 111400 & 877,06 & 858,38 & 911,85 & 938,55 \\
30 & 108200 & 856,69 & 837,84 & 890,87 & 918,65 \\
29 & 105000 & 835,53 & 816,65 & 869,15 & 897,89 \\
28 & 101800 & 813,53 & 794,77 & 846,65 & 876,24 \\
27 & 98600 & 790,69 & 772,18 & 823,34 & 853,67 \\
26 & 95400 & 767,03 & 748,87 & 799,20 & 830,17 \\
25 & 92200 & 742,52 & 724,77 & 774,18 & 805,68 \\
24 & 89000 & 717,98 & 700,59 & 749,02 & 781,03
\end{tabular}




\begin{tabular}{|c|c|c|c|c|c|}
\hline 23 & 85800 & 692,77 & 675,77 & 723,13 & 755,59 \\
\hline 22 & 82600 & 666,90 & 650,34 & 696,53 & 729,36 \\
\hline 21 & 79400 & 640,40 & 624,33 & 669,24 & 702,36 \\
\hline 20 & 76200 & 613,33 & 597,80 & 641,32 & 674,65 \\
\hline 19 & 73000 & 585,76 & 570,81 & 612,81 & 646,27 \\
\hline 18 & 69800 & 557,76 & 543,41 & 583,78 & 617,29 \\
\hline 17 & 66600 & 529,39 & 515,65 & 554,28 & 587,77 \\
\hline 16 & 63400 & 500,68 & 487,56 & 524,33 & 557,73 \\
\hline 15 & 60200 & 472,36 & 459,78 & 494,67 & 527,95 \\
\hline 14 & 57000 & 443,84 & 431,80 & 464,71 & 497,80 \\
\hline 13 & 53800 & 415,19 & 403,69 & 434,54 & 467,36 \\
\hline 12 & 50600 & 386,50 & 375,53 & 404,25 & 436,70 \\
\hline 11 & 47400 & 357,85 & 347,41 & 373,92 & 405,90 \\
\hline 10 & 44200 & 329,33 & 319,42 & 343,65 & 375,04 \\
\hline 9 & 41000 & 301,03 & 291,64 & 313,55 & 344,22 \\
\hline 8 & 37800 & 273,05 & 264,20 & 283,74 & 313,54 \\
\hline 7 & 34600 & 245,50 & 237,17 & 254,36 & 283,06 \\
\hline 6 & 31400 & 219,03 & 211,20 & 226,14 & 253,55 \\
\hline 5 & 28200 & 192,91 & 185,61 & 198,36 & 224,21 \\
\hline 4 & 25000 & 167,21 & 160,43 & 171,05 & 195,00 \\
\hline 3 & 21800 & 141,46 & 135,44 & 144,05 & 165,55 \\
\hline 2 & 18600 & 114,89 & 109,80 & 116,51 & 134,88 \\
\hline GF & 12600 & 61,47 & 58,67 & 61,94 & 72,51 \\
\hline LGM & 9000 & 35,34 & 33,71 & 35,47 & 41,81 \\
\hline LG & 6000 & 18,08 & 17,24 & 18,08 & 21,45 \\
\hline B1 & 3000 & 5,47 & 5,21 & 5,45 & 6,50 \\
\hline B2 & 0 & 0,00 & 0,00 & 0,00 & 0,00 \\
\hline
\end{tabular}

Tabel 3. Simpangan arah Y.

\begin{tabular}{cccccc}
\hline \multirow{2}{*}{ Lantai } & $\begin{array}{c}\text { Tinggi Lantai } \\
(\mathrm{mm})\end{array}$ & \multicolumn{4}{c}{ Simpangan Antar Lantai Arah Y (mm) } \\
& & Model Asli & Model 1 & Model 2 & Model 3 \\
\hline LMR ROOF & 122600 & 926,13 & 931,22 & 944,63 & 934,63 \\
LMR & 119600 & 916,33 & 920,77 & 934,25 & 924,30 \\
32 & 114600 & 888,72 & 892,75 & 906,43 & 897,09 \\
31 & 111400 & 872,39 & 876,12 & 889,86 & 880,81 \\
30 & 108200 & 854,26 & 857,79 & 871,57 & 862,86 \\
29 & 105000 & 834,25 & 837,71 & 851,47 & 843,13 \\
28 & 101800 & 812,54 & 816,05 & 829,71 & 821,78 \\
27 & 98600 & 789,27 & 792,93 & 806,40 & 798,90 \\
26 & 95400 & 764,50 & 768,45 & 781,56 & 774,52 \\
25 & 92200 & 738,12 & 742,49 & 755,08 & 748,55 \\
24 & 89000 & 714,88 & 719,05 & 731,64 & 725,72 \\
23 & 85800 & 690,46 & 694,51 & 707,00 & 701,75 \\
22 & 82600 & 665,09 & 669,08 & 681,36 & 676,79 \\
21 & 79400 & 638,88 & 642,84 & 654,82 & 650,95 \\
20 & 76200 & 611,92 & 615,89 & 627,50 & 624,32 \\
19 & 73000 & 584,31 & 588,29 & 599,47 & 596,99 \\
18 & 69800 & 556,11 & 560,13 & 570,81 & 569,00
\end{tabular}


Wendi, Rafki dan Romi, Effect Of Shear Wall On Building Stru...

\begin{tabular}{cccccc}
\hline 17 & 66600 & 527,37 & 531,46 & 541,56 & 540,41 \\
16 & 63400 & 497,98 & 502,19 & 511,64 & 511,17 \\
15 & 60200 & 471,01 & 474,93 & 484,05 & 484,26 \\
14 & 57000 & 443,61 & 447,27 & 456,02 & 456,91 \\
13 & 53800 & 416,01 & 419,41 & 427,74 & 429,28 \\
12 & 50600 & 388,31 & 391,46 & 399,32 & 401,47 \\
11 & 47400 & 360,64 & 363,53 & 370,88 & 373,60 \\
10 & 44200 & 333,09 & 335,71 & 342,55 & 345,76 \\
9 & 41000 & 305,75 & 308,10 & 314,41 & 318,04 \\
8 & 37800 & 278,72 & 280,79 & 286,58 & 290,54 \\
7 & 34600 & 252,06 & 253,86 & 259,12 & 263,32 \\
6 & 31400 & 226,47 & 227,90 & 232,72 & 237,07 \\
5 & 28200 & 201,34 & 202,42 & 206,82 & 211,18 \\
4 & 25000 & 176,74 & 177,47 & 181,44 & 185,69 \\
3 & 21800 & 152,38 & 152,77 & 156,25 & 160,27 \\
2 & 18600 & 126,85 & 126,94 & 129,82 & 133,46 \\
GF & 12600 & 65,78 & 65,83 & 67,55 & 69,62 \\
LGM & 9000 & 38,87 & 38,79 & 39,81 & 41,17 \\
LG & 6000 & 21,30 & 21,19 & 21,68 & 22,50 \\
B1 & 3000 & 7,19 & 7,14 & 7,24 & 7,55 \\
B2 & 0 & 0,00 & 0,00 & 0,00 & 0,00 \\
\hline
\end{tabular}

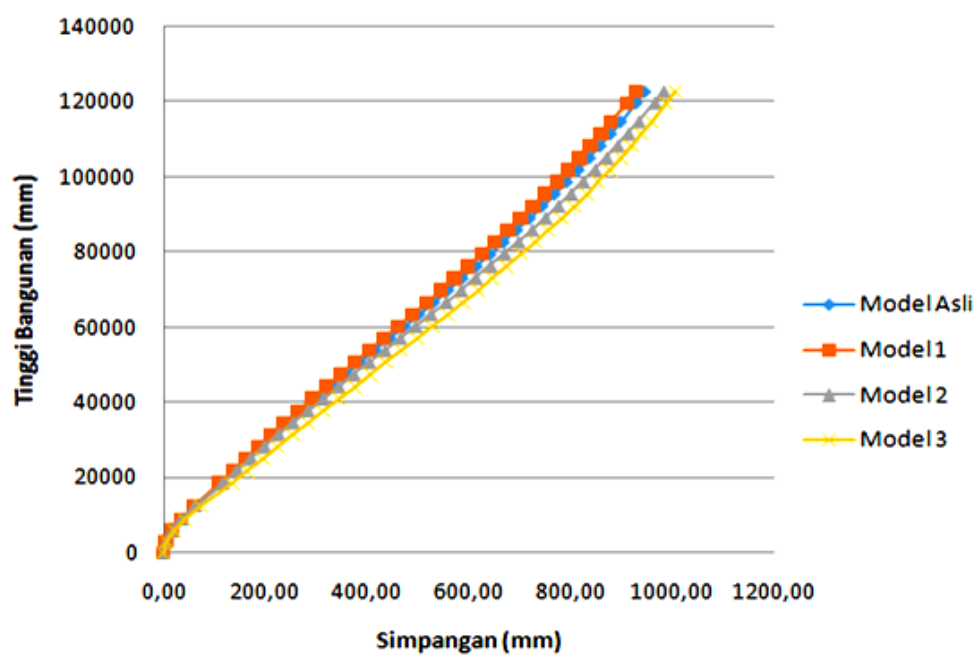

Gambar 7. Grafik simpangan arah X.

Pada Gambar 7 dapat dilihat, simpangan yang paling besar terjadi pada model-3 dan simpangan yang paling kecil terdapat pada model-1. 


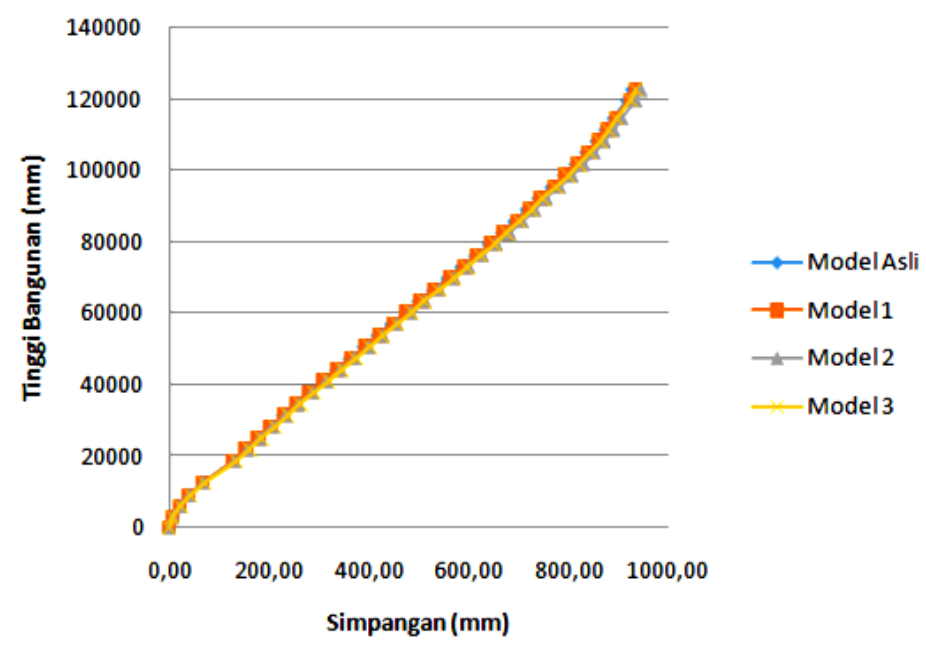

Gambar 8. Grafik simpangan arah Y.

Pada Gambar 8 terlihat bahwa simpangan yang paling besar terjadi pada model-2 dan simpangan yang paling kecil terdapat pada model asli.

\section{Analisis Base Shear}

Analisis base shear terbagi atas empat pemodelan pada arah $\mathrm{X}$ dan $\mathrm{Y}$ seperti yang ditunjukkan pada Tabel 4 dan 5.

Tabel 4. Base Shear arah X.

\begin{tabular}{cccccc}
\hline & Tinggi lantai & \multicolumn{3}{c}{ Shear antar lantai arah X / VX (TON) } \\
Lantai & $(\mathrm{mm})$ & $\begin{array}{c}\text { Model } \\
\text { Asli }\end{array}$ & Model 1 & Model 2 & Model 3 \\
\hline LMR & 122600 & 196,58 & 196,88 & 194,57 & 191,07 \\
ROOF & 119600 & 435,03 & 435,14 & 430,30 & 421,13 \\
LMR & 114600 & 668,26 & 668,11 & 661,00 & 646,63 \\
32 & 111400 & 881,56 & 881,28 & 872,16 & 853,80 \\
31 & 108200 & 1090,39 & 1089,96 & 1078,99 & 1056,97 \\
30 & 108200 & 1294,51 & 1293,90 & 1281,25 & 1255,91 \\
29 & 101800 & 1493,70 & 1492,89 & 1478,71 & 1450,36 \\
28 & 98600 & 1687,72 & 1686,70 & 1671,13 & 1640,08 \\
27 & 95400 & 1876,33 & 1875,09 & 1858,27 & 1824,84 \\
26 & 92200 & 2064,18 & 2062,70 & 2044,77 & 2009,65 \\
25 & 89000 & 2251,77 & 2250,03 & 2231,14 & 2195,13 \\
24 & 85800 & 2433,16 & 2431,16 & 2411,43 & 2374,80 \\
23 & 82600 & 2608,13 & 2605,86 & 2585,42 & 2548,47 \\
22 & 79400 & 2776,49 & 2773,89 & 2752,91 & 2715,92 \\
21 & 76200 & 2938,07 & 2935,20 & 2913,72 & 2876,95 \\
20 & 73000 & 3092,69 & 3089,57 & 3067,67 & 3031,39 \\
19 & 69800 & 3240,21 & 3236,85 & 3214,60 & 3179,06 \\
18 & 66600 & 3380,50 & 3376,91 & 3354,36 & 3319,78 \\
17 & & & & &
\end{tabular}




\begin{tabular}{cccccc}
\hline & & & & & \\
16 & 63400 & 3516,41 & 3512,48 & 3489,83 & 3456,66 \\
15 & 60200 & 3648,12 & 3643,68 & 3621,12 & 3589,85 \\
14 & 57000 & 3772,04 & 3767,06 & 3744,66 & 3715,49 \\
13 & 53800 & 3888,11 & 3882,67 & 3860,36 & 3833,48 \\
12 & 50600 & 3996,26 & 3990,39 & 3968,17 & 3943,74 \\
11 & 47400 & 4096,47 & 4090,20 & 4068,04 & 4046,21 \\
10 & 44200 & 4188,72 & 4182,10 & 4159,95 & 4140,84 \\
9 & 41000 & 4273,03 & 4266,08 & 4243,91 & 4227,60 \\
8 & 37800 & 4349,43 & 4342,19 & 4319,92 & 4306,50 \\
7 & 34600 & 4419,21 & 4411,66 & 4389,29 & 4378,92 \\
6 & 31400 & 4482,54 & 4474,66 & 4452,17 & 4445,02 \\
5 & 28200 & 4538,04 & 4529,89 & 4507,22 & 4503,23 \\
4 & 25000 & 4585,80 & 4577,44 & 4554,53 & 4553,59 \\
3 & 21800 & 4625,91 & 4617,42 & 4594,22 & 4596,13 \\
2 & 18600 & 4663,48 & 4654,84 & 4631,36 & 4636,19 \\
GF & 12600 & 4683,85 & 4675,12 & 4651,39 & 4657,93 \\
LGM & 9000 & 4693,87 & 4685,14 & 4661,24 & 4668,68 \\
LG & 6000 & 4698,86 & 4690,15 & 4666,15 & 4674,08 \\
B1 & 3000 & 4700,40 & 4691,71 & 4667,66 & 4675,77 \\
\hline
\end{tabular}

Tabel 4. Base Shear arah Y.

\begin{tabular}{cccccc}
\hline Lantai & $\begin{array}{c}\text { Tinggi lantai } \\
(\mathrm{mm})\end{array}$ & \multicolumn{3}{c}{ Shear antar lantai arah Y / VY (TON) } \\
& & Model asli & Model 1 & Model 2 & Model 3 \\
\hline LMR ROOF & 122600 & 200,22 & 201,53 & 200,58 & 199,57 \\
LMR & 119600 & 443,91 & 446,52 & 444,77 & 441,02 \\
32 & 114600 & 681,61 & 685,46 & 683,02 & 676,48 \\
31 & 111400 & 898,73 & 903,78 & 900,68 & 891,97 \\
30 & 108200 & 1111,08 & 1117,29 & 1113,59 & 1102,74 \\
29 & 108200 & 1318,31 & 1325,67 & 1321,43 & 1308,44 \\
28 & 101800 & 1520,14 & 1528,62 & 1523,90 & 1508,80 \\
27 & 98600 & 1716,27 & 1725,85 & 1720,72 & 1703,51 \\
26 & 95400 & 1906,40 & 1917,06 & 1911,60 & 1892,29 \\
25 & 92200 & 2095,11 & 2106,85 & 2101,12 & 2080,06 \\
24 & 89000 & 2283,38 & 2296,16 & 2290,23 & 2267,88 \\
23 & 85800 & 2465,21 & 2478,97 & 2472,90 & 2449,29 \\
22 & 82600 & 2640,37 & 2655,07 & 2648,89 & 2624,08 \\
21 & 79400 & 2808,64 & 2824,18 & 2817,99 & 2792,02 \\
20 & 76200 & 2969,85 & 2986,24 & 2980,03 & 2952,95 \\
19 & 73000 & 3123,83 & 3141,02 & 3134,81 & 3106,68 \\
18 & 69800 & 3270,40 & 3288,37 & 3282,20 & 3253,05 \\
17 & 66600 & 3409,44 & 3428,14 & 3422,03 & 3391,93 \\
16 & 63400 & 3543,75 & 3563,03 & 3557,16 & 3526,28 \\
15 & 60200 & 3673,83 & 3693,48 & 3688,03 & 3656,62 \\
14 & 57000 & 3796,15 & 3816,10 & 3811,09 & 3779,21
\end{tabular}




\begin{tabular}{cccccc}
13 & 53800 & 3910,64 & 3930,89 & 3926,28 & 3893,99 \\
12 & 50600 & 4017,26 & 4037,77 & 4033,55 & 4000,89 \\
11 & 47400 & 4115,99 & 4136,74 & 4132,89 & 4099,93 \\
10 & 44200 & 4206,87 & 4227,81 & 4224,31 & 4191,09 \\
9 & 41000 & 4289,91 & 4311,03 & 4307,85 & 4274,44 \\
8 & 37800 & 4365,20 & 4386,46 & 4383,59 & 4350,02 \\
7 & 34600 & 4434,06 & 4455,38 & 4452,85 & 4419,24 \\
6 & 31400 & 4496,66 & 4517,96 & 4515,81 & 4482,26 \\
5 & 28200 & 4551,71 & 4572,97 & 4571,16 & 4537,68 \\
4 & 25000 & 4599,38 & 4620,59 & 4619,08 & 4585,69 \\
3 & 21800 & 4639,83 & 4661,00 & 4659,74 & 4626,44 \\
2 & 18600 & 4678,26 & 4699,29 & 4698,33 & 4665,13 \\
GF & 12600 & 4698,52 & 4719,46 & 4718,68 & 4685,58 \\
LGM & 9000 & 4708,66 & 4729,57 & 4728,85 & 4695,82 \\
LG & 6000 & 4713,94 & 4734,83 & 4734,13 & 4701,13 \\
B1 & 3000 & 4715,69 & 4736,57 & 4735,88 & 4702,88 \\
\hline
\end{tabular}

Berdasarkan Tabel 4 dan 5, besarnya base shear yang terjadi semakin ke bawah nilainya bertambah besar, seperti yang ditunjukkan pada Gambar 10 dan 11.

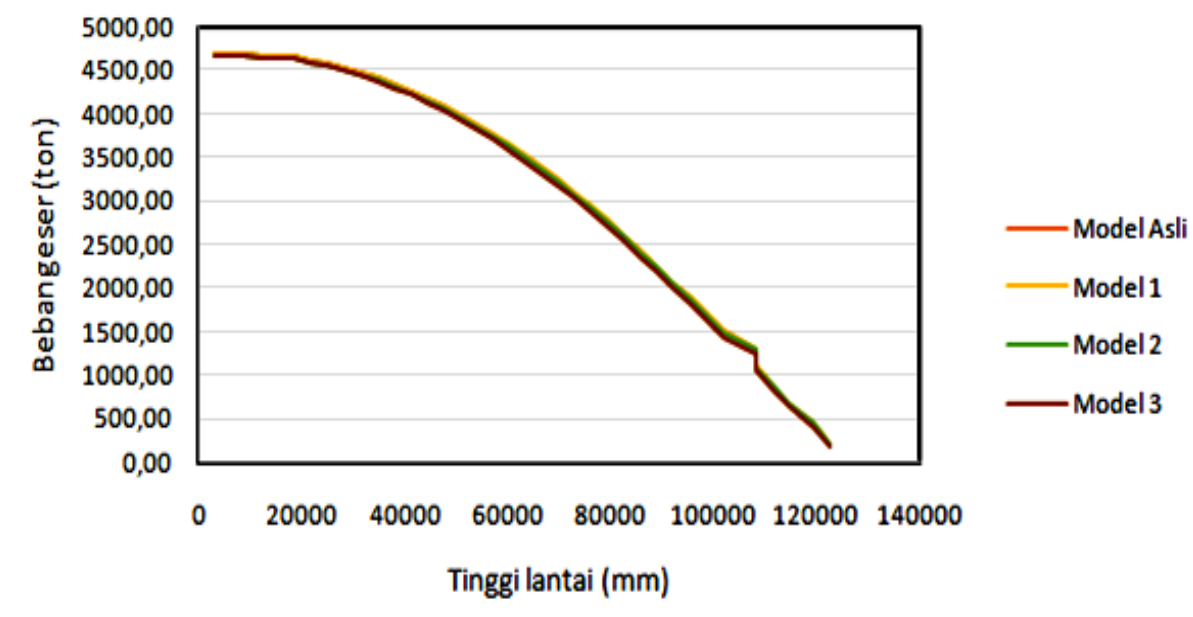

Gambar 9. Grafik Base Shear arah X.

Pada Gambar 9 dapat dilihat bahwa beban geser mulai dari lantai paling atas sampai bawah semakin besar. Beban yang paling besar terdapat pada model-1 dan beban yang paling kecil berada pada model-3. 


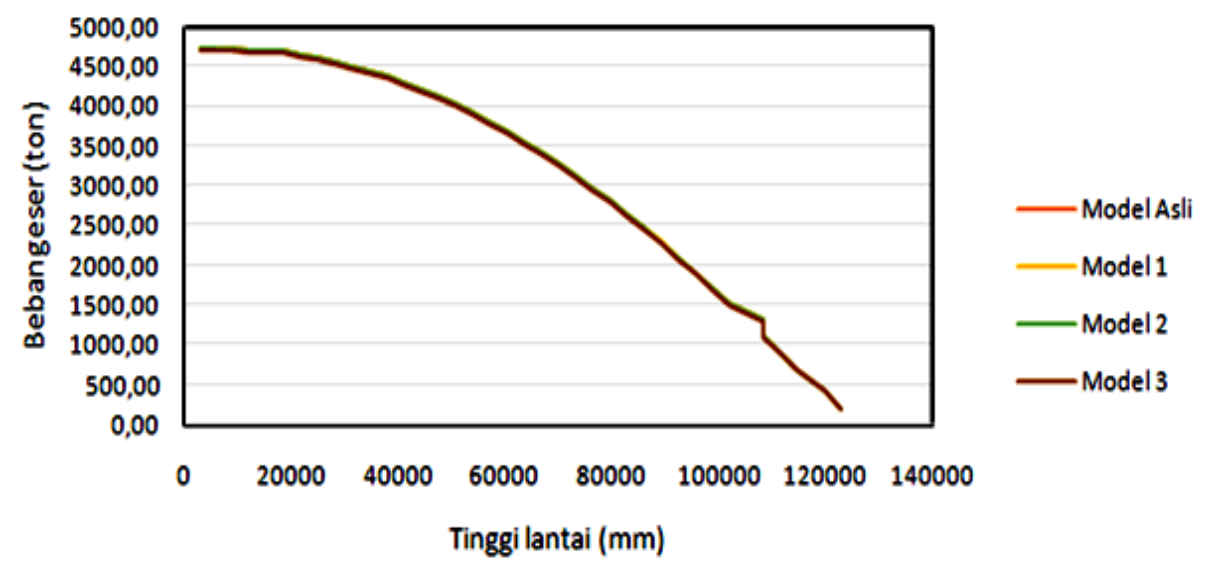

Gambar 10. Grafik Base Shear arah Y.

Pada Gambar 10 dapat dilihat bahwa beban geser mulai dari lantai paling atas sampai bawah semakin besar. Beban yang paling besar berada pada model-1 dan beban yang paling kecil berada pada model asli.

\section{KESIMPULAN}

Penempatan shear wall dengan empat pemodelan yang dianalisis menggunakan software ETABS berdasarkan ketentuan SNI 1726:2012, SNI 03-1727-1989, PPIUG 1983. Aturan yang ditetapkan dalam masing-masing SNI sangat membantu dalam menyelesaikan penelitian ini, seperti pengkategorian risiko bangunan yang diteliti termasuk dalam kategori risiko II. Berdasarkan hasil simpangan dan base shear pada arah X dan arah Y dari empat pemodelan perletakan shear wall Gedung Tower B Trans Park dan Trans Studio Cibubur, model-1 merupakan yang paling efisien dalam menahan beban gempa. Dengan nilai simpangan arah $X$ adalah 926,62 $\mathrm{mm}$ dan simpangan arah Y.

\section{DAFTAR PUSTAKA}

[1] http://www.google.com

[2] Hanif, B.A (2014) Analisis Pengaruh Shear Wall terhadap Simpangan Struktur Gedung akibat Gempa Dinamis. Jurnal Konstruksia, 5 (2), 79-101.

[3] SNI: 1726-2012 (2012) Tatacara Perencanaan Ketahanan Gempa untuk Struktur Bangunan Gedung dan Non-Gedung. Kementerian Pekerjaan Umum. Jakarta

[4] SNI: 03-1727-1989 (2002) Pedoman Perencanaan Pembebanan untuk Rumah dan Gedung. Kementerian pekerjaan Umum. Jakarta.

[5] Peraturan Pembangunan Indonesia untuk Gedung (1983) Kementerian Pekerjaan Umum. Jakarta.

[6] Sahputra, R., Taufik., Khaidir, I (2015) Tinjau Ulang Perencanaan Struktur Gedung Dinas Pengelolaan Keuangan daerah (DPKD) Sumbar. Jurnal Fakultas Teknik Sipil, UBH 1 (1), 122-135. 